\title{
Protocol
}

\section{Confirming Antibody Specificity in Xenopus}

\author{
Sian A. Martin, ${ }^{1}$ Suzannah J. Page, ${ }^{1}$ Maya Z. Piccinni, ${ }^{2}$ and Matthew J. Guille ${ }^{1,2,3}$ \\ ${ }^{1}$ Molecular Embryology Laboratory, University of Portsmouth, Portsmouth, Hampshire PO1 2DY, United \\ Kingdom; ${ }^{2}$ European Xenopus Resource Centre, Institute of Biological and Biomedical Sciences, University of \\ Portsmouth, Portsmouth, Hampshire PO1 2DY, United Kingdom
}

Verifying that a new antibody recognizes its target can be difficult. In this protocol, expression of a target protein in Xenopus embryos is either knocked down using CRISPR-Cas9 technology (for zygotic proteins) or enhanced by microinjection of a synthetic mRNA (for maternal proteins). Western blotting analysis is then performed. If the antibody recognizes the target protein, the western blot will show a relatively weak band for CRISPR-injected embryos and a relatively strong band for RNAinjected embryos. This represents a straightforward, powerful strategy for confirming antibody specificity in Xenopus.

It is essential that you consult the appropriate Material Safety Data Sheets and your institution's Environmental Health and Safety Office for proper handling of equipment and hazardous materials used in this protocol.

RECIPES: Please see the end of this protocol for recipes indicated by $<R>$. Additional recipes can be found online at http://cshprotocols.cshlp.org/site/recipes.

Agarose gel electrophoresis reagents (i.e., $1 \%-2 \%$ agarose gels, loading dye, running buffer, and ethidium bromide)

Antibody to test

See Protocol: Raising Antibodies for Use in Xenopus (Piccinni and Guille 2020).

Cysteine (2\% [w/v], pH 7.8; Sigma-Aldrich C7352)

Embryo extraction buffer $<\mathrm{R}>$

Ficoll (3\% [w/v], prepared in 1× MBS; Sigma-Aldrich GE17-0300-50)

Freon (1,1,2-trichloro-1,2,2-trifluoroethane; Fisher Scientific T1781)

Modified Barth's saline (MBS) $(1 \times, \mathrm{pH} 7.8)<\mathrm{R}>$

Nuclease-free $\mathrm{dH}_{2} \mathrm{O}$ (Fisher Scientific 15303711)

Reagents for CRISPR analysis only (see Steps 1-9 and Steps 25-33)

Cas9 protein (EnGen Cas9 NLS, Streptococcus pyogenes [NEB M0646])

DNeasy Blood \& Tissue Kit (QIAGEN) or other appropriate kit to prepare genomic DNA from embryos

\footnotetext{
${ }^{3}$ Correspondence: matthew.guille@port.ac.uk

From the Xenopus collection, edited by Hazel L. Sive.

(C) 2020 Cold Spring Harbor Laboratory Press

Cite this protocol as Cold Spring Harb Protoc; doi:10.1101/pdb.prot105601
} 
gDNA oligo $\left(100 \mu \mathrm{M}\right.$, dissolved in $\left.\mathrm{H}_{2} \mathrm{O}\right)$

MEGAshortscript T7 Transcription Kit (Thermo Fisher Scientific AM1354)

$\mathrm{MgCl}_{2}(500 \mu \mathrm{M})$

NEBuffer2 (NEB B7002S)

PCR master mix $(2 \times$; see Table 1$)$

PCR primers designed to amplify 600-800 bp containing the CRISPR target site close to the amplicon's center (for Step 26)

Q5 Hot Start High-Fidelity $2 \times$ Master Mix (NEB M0491S)

T7 Endonuclease I (NEB M0302)

Universal $3^{\prime}$ gRNA template (5' AAAAGCACCGACTCGGTGCCACTTTTTCAAGTTGATAAC GGACTAGCCTTATTTTAACTTGCTATTTCTAGCTCTAAAAC 3') (100 $\mu \mathrm{M})$

Reagents for overexpression analysis only (see Steps 10-17)

Plasmid encoding the target ORF surrounded by the globin UTRs driven by a T7, SP6, or T3 promoter (e.g., pCS2 [Rupp et al. 1994])

Such plasmids are available from the European Xenopus Resource Centre (EXRC), which also holds ORFeomes (representing more than 14000 genes).

Restriction enzyme appropriate to cut plasmid encoding the target ORF (see Step 11)

SuperScript kit (Ambion) for long transcripts

Choose a kit based on which promoter is in the plasmid encoding the protein.

SDS-PAGE reagents (i.e., sample buffer, gel, and running buffer; see Step 35)

Western blotting reagents (see Step 36)

Xenopus eggs, fertilized (see Guille 1999)

If targeting a specific protein with CRISPR, consider your choice of species (see Step 1). If Xenopus tropicalis is available, its rarity of gene duplications makes it preferable to Xenopus laevis for the $\sim 60 \%$ of genes that have homeologs in the latter.

Equipment

Access to a sequencer (see Step 33)

Agarose gel electrophoresis apparatus

Benchtop centrifuge

Filter tips for pipettes

Flame-polished glass Pasteur pipettes, with a bore slightly larger than embryos

Glass needles for use in a microinjector

Incubators $\left(18^{\circ} \mathrm{C}\right.$ for $X$. laevis embryos; $25^{\circ} \mathrm{C}$ for $X$. tropicalis embryos)

Injection dish (mesh or agarose; prepared in house as described by Guille [1999])

Microinjector

Parafilm

PCR clean-up columns (for overexpression analysis only; see Steps 10-17)

Programs for designing sgRNAs (e.g., CRISPRscan; see Step 1) and TIDE analysis (see Step 33)

(for CRISPR analysis only)

SDS-PAGE gel electrophoresis apparatus

SigmaSpin Sequencing Reaction Clean-Up columns (for CRISPR analysis only; see Steps 1-9)

Spectrophotometer capable of measuring microliter volumes

Sterile microcentrifuge tubes

Sterile PCR tubes

Thermocycler

Vortex mixer

Western blot transfer and imaging systems 
Martin et al.

\section{METHOD}

\section{Preparation of Single Guide RNA (sgRNA) or Synthetic RNA}

To synthesize sgRNA for knocking down a target protein in Xenopus embryos by CRISPR, begin with Steps 1-9. To prepare synthetic RNA for overexpressing a target protein in Xenopus embryos, begin with Steps 10-17. The former strategy is best for zygotic proteins, whereas the latter is best for maternal proteins (see Discussion).

\section{Design and In Vitro Transcription of sgRNA (for CRISPR Only)}

This is best suited to zygotic proteins.

1. Design sgRNAs.

This can be done using a variety of programs. We have had great success using CRISPRscan (http://www .crisprscan.org) to target the first or second translated exon of the gene encoding the protein against which the antibody was raised. If working in X. laevis, then both homeologs will almost certainly need to be targeted; it is, however, worth checking that both of the genes are transcribed at significant levels by using the expression tab on Xenbase. We normally design three sgRNAs for each gene because there is variability in their effectiveness.

2. Prepare the PCR mix by combining reagents as outlined in Table 1 . Remove $3 \mu \mathrm{L}$ before reaction and place on ice.

3. Anneal and extend the sgRNA template (ssDNA) oligos in a thermocycler using the program outlined in Table 1.

4. Run pre- and postreaction $(3-\mu \mathrm{L})$ samples on a $2 \%$ agarose gel using standard procedures.

Ensure that the postreaction band is much stronger with slightly lower mobility compared to the prereaction band.

5. Perform the in vitro transcription reaction according to the MEGAshortscript T7 Transcription Kit instructions, using $2 \mu \mathrm{L}$ of the PCR from Step 3. Ensure that the reaction is set up at room temperature and not on ice.

Because only $2 \mu \mathrm{L}$ of the PCR is used, the remaining DNA can be stored at $-20^{\circ} \mathrm{C}$.

6. Remove small molecules from the reaction by spinning through a SigmaSpin Sequencing Reaction Clean-Up column following the manufacturer's instructions.

7. Run $3 \mu \mathrm{L}$ of sgRNA plus loading buffer on a $2 \%$ agarose gel for $15 \mathrm{~min}$. A single band should be visible.

8. Quantify the sgRNA by measuring the $A_{260}$ of $1 \mu \mathrm{L}$ of sgRNA using a suitable spectrophotometer.

9. Store the sgRNA at $-80^{\circ} \mathrm{C}$ in 300 -ng aliquots.

Proceed to Step 18.

TABLE 1. Components and steps to synthesize dsDNA from ssDNA by an annealing-extension reaction

\begin{tabular}{|c|c|c|c|c|}
\hline PCR components & $\begin{array}{l}\text { PCR master mix }(2 \times) \\
\text { gDNA oligo }(100 \mu \mathrm{m}) \\
\text { Universal gRNA template }(100 \mu \mathrm{m}) \\
\mathrm{MgCl}_{2}(500 \mu \mathrm{M}) \\
\text { Nuclease-free } \mathrm{dH}_{2} \mathrm{O} \\
\text { Reaction total }\end{array}$ & $\begin{array}{l}50 \mu \mathrm{L} \\
2 \mu \mathrm{L} \\
2 \mu \mathrm{L} \\
2 \mu \mathrm{L} \\
44 \mu \mathrm{L} \\
100 \mu \mathrm{L}\end{array}$ & & \\
\hline Reaction steps & $\begin{array}{l}1 \text { cycle } \\
20 \text { cycles }\end{array}$ & $\begin{array}{l}\text { Initial denaturing } \\
\text { Denaturing } \\
\text { Annealing } \\
\text { Extension } \\
\text { Final extension } \\
\text { Hold }\end{array}$ & $\begin{array}{l}94^{\circ} \mathrm{C} \\
94^{\circ} \mathrm{C} \\
58^{\circ} \mathrm{C} \\
68^{\circ} \mathrm{C} \\
68^{\circ} \mathrm{C} \\
4^{\circ} \mathrm{C}\end{array}$ & $\begin{array}{l}5 \mathrm{~min} \\
20 \mathrm{sec} \\
15 \mathrm{sec} \\
15 \mathrm{sec} \\
5 \mathrm{~min}\end{array}$ \\
\hline
\end{tabular}


Preparation of Synthetic RNA (for Overexpression Analysis Only)

This is best suited to maternal proteins.

10. Prepare plasmid encoding the target ORF surrounded by the globin UTRs driven by a T7, SP6, or T3 promoter (e.g., pCS2 [Rupp et al. 1994]).

11. Linearize $10 \mu \mathrm{g}$ of plasmid with a unique restriction enzyme that cuts downstream from the synthetic poly(A) site or polyadenylation signal (depending on the plasmid).

12. Purify the DNA using a PCR clean-up column and resuspend it at $1 \mathrm{mg} / \mathrm{mL}$ in nucleasefree water.

13. Use this DNA as a template to synthesize RNA with the appropriate Ambion SuperScript kit following the manufacturer's instructions. Ensure that the reaction is set up at room temperature.

14. Remove small molecules from the reaction by spinning through a SigmaSpin sequencing reaction cleanup column following the manufacturer's instructions.

15. Run $1 \mu \mathrm{L}$ of RNA on a $1 \%$ agarose gel.

A bright band should be visible. If multiple bands are seen, these most often represent conformers of the RNA and can be resolved to a single band in a denaturing gel.

16. Quantify the synthetic RNA by measuring $A_{260}$ of $1 \mu \mathrm{L}$ of the sample using a suitable spectrophotometer.

17. Store the RNA in single-use $2-\mu \mathrm{L}$ aliquots at $-80^{\circ} \mathrm{C}$.

Proceed to Step 18.

Injection into Fertilized Xenopus Eggs

18. Calibrate an injection needle to inject $4 \mathrm{~nL}$ of liquid. Keep the needle tip hydrated in a dish of nuclease-free $\mathrm{dH}_{2} \mathrm{O}$ when it is not in use.

19. When fertilized Xenopus eggs have turned their animal poles uppermost, add a solution of $2 \%$ $(\mathrm{w} / \mathrm{v})$ cysteine $(\mathrm{pH}$ 7.8) prepared in water. Agitate the embryos gently for $5 \mathrm{~min}$ at room temperature until they have been dejellied, and then wash them five times at room temperature in $1 \times$ MBS.

Each wash should be of sufficient length to allow the embryos to settle after swirling to mix them with the MBS.

20. Prepare the injection solution.

\section{For CRISPR-Cas9}

i. Prepare the injection mixture by combining $16 \mu \mathrm{M}$ Cas9 protein, $200 \mathrm{ng}$ sgRNA, and nuclease-free $\mathrm{H}_{2} \mathrm{O}$ to $4 \mu \mathrm{L}$.

A second injection mix without sgRNA may be prepared and injected as a control.

ii. Mix gently, and centrifuge at full speed in a benchtop centrifuge for $1 \mathrm{~min}$ at room temperature.

\section{For synthetic RNA}

iii. Prepare $1 \mu \mathrm{g}$ of synthetic RNA in $4 \mu \mathrm{L}$ of nuclease-free $\mathrm{H}_{2} \mathrm{O}$.

iv. Mix gently, and centrifuge at full speed in a benchtop centrifuge for $1 \mathrm{~min}$ at room temperature.

21. Place a 1- to $3-\mu \mathrm{L}$ droplet of injection solution onto a square of Parafilm, and fill the needle from the droplet.

22. Fill an injection dish with $3 \%(\mathrm{w} / \mathrm{v})$ Ficoll in $1 \times$ MBS. Transfer $50-100$ embryos to the injection dish using a precut glass pipette. 
Martin et al.

23. Inject the solution into the animal pole of each embryo.

24. Once injected, transfer the embryos into an incubator at the appropriate temperature and wait $3-$ $4 \mathrm{~h}$ before transferring them to $0.1 \times$ MBS and removing damaged embryos.

Continue with Step 25 if the CRISPR analysis was performed, or proceed to western blotting (Steps 34-36) if synthetic RNA was injected for overexpression of the protein of interest.

\section{T7 Endonuclease Assay and TIDE Analysis (for CRISPR Only)}

The T7 endonuclease assay is used to confirm specific cutting by Cas9, validating the sgRNA used. TIDE analysis gives an approximate efficiency reading for the cutting of a specific site using a specific sgRNA.

\section{T7 Endonuclease Assay}

25. Prepare genomic DNA from embryos at stage 12 or later. Use an appropriate kit and follow the manufacturer's instructions. Store the genomic DNA at $-20^{\circ} \mathrm{C}$.

We use QIAGEN's DNeasy Blood \& Tissue Kit.

26. Perform PCR by combining $100 \mathrm{ng}$ of genomic DNA, $10 \mu \mathrm{M}$ of forward primer, $10 \mu \mathrm{M}$ of reverse primer, $25 \mu \mathrm{L}$ of Q5 Hot Start High-Fidelity $2 \times$ Master Mix (which includes enzyme), and nuclease-free $\mathrm{dH}_{2} \mathrm{O}$ to $50 \mu \mathrm{L}$. Include a reaction with DNA from an uninjected embryo as a control. Amplify using a basic amplification program with primer-specific annealing temperatures.

27. Run $3 \mu \mathrm{L}$ of the amplicon mixed with $1 \mu \mathrm{L}$ of loading solution on a $1 \%$ agarose gel.

28. Use spectrophotometry to measure the amplicon concentration.

29. Combine $2 \mu \mathrm{L}$ of NEBuffer 2, $\sim 200 \mathrm{ng}$ of amplicon, and nuclease-free $\mathrm{dH}_{2} \mathrm{O}$ for a final volume of $19 \mu \mathrm{L}$.

30. Denature the amplicon for $5 \mathrm{~min}$ at $95^{\circ} \mathrm{C}$. Reanneal by cooling to $25^{\circ} \mathrm{C}$ at a rate of $0.1^{\circ} \mathrm{C} \mathrm{sec}-1$ in a thermocycler, and then hold at $4^{\circ} \mathrm{C}$.

31. Add $1 \mu \mathrm{L}$ of $\mathrm{T} 7$ endonuclease $\mathrm{I}$ and incubate for $15 \mathrm{~min}$ at $37^{\circ} \mathrm{C}$.

32. Visualize the products of the digestion on a $1.5 \%$ agarose gel.

T7 endonuclease will only cut at indels. Successful cutting will show two bands on a gel (or, if the cut site is in the center of the amplicon, there will appear to be one band at one-half the size of the amplicon).

\section{TIDE Analysis}

33. Sequence the amplicon obtained from Step 26 and analyze using TIDE, which uses algorithms to distinguish the different sequences that occur after the CRIPSR cut site to predict where and how often the main indels have occurred (https://tide.deskgen.com/).

Once cut site digestion has been achieved at a good efficiency rate, proceed to western blot experiments (Steps 34-36) to test antibodies.

\section{Western Blot Analysis}

To choose which developmental stages to target for the western analysis, use the mRNA expression information on Xenbase as a guide. Although it is clear that translational control is used in early development, using stages at which mRNA levels are highest is the best starting point. This method is described in detail in Guille and Robinson (1999).

34. Prepare a crude protein extract.

i. For each experimental condition, gather 25 embryos.

ii. Add $250 \mu \mathrm{L}$ of embryo extraction buffer, and pipette up and down with a 1-mL pipette until the homogenate is uniform.

iii. Add an equal amount of Freon, and vortex for $30 \mathrm{sec}$. 


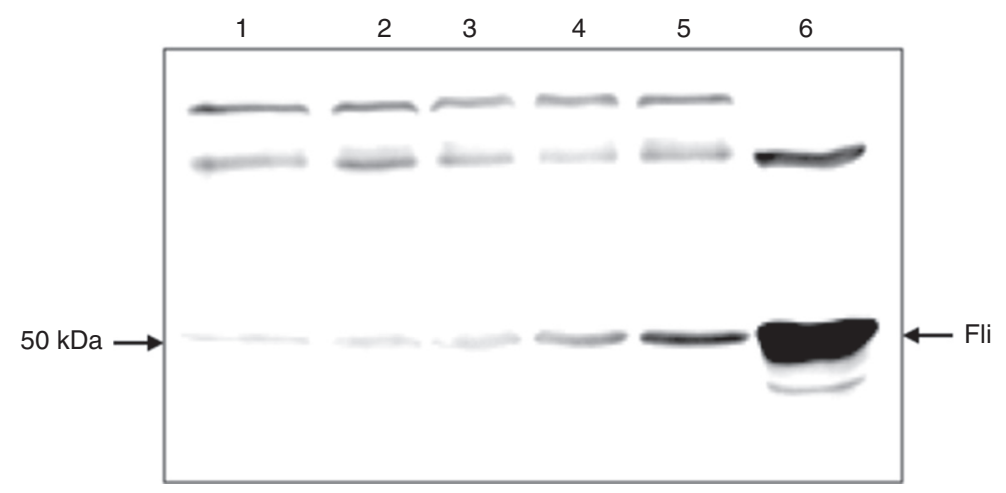

FIGURE 1. Western blot analysis of Fli1 protein overexpression in Xenopus laevis embryos. One-cell-stage Xenopus laevis embryos were injected with either $\mathrm{H}_{2} \mathrm{O}$ (as a control; lane 1) or increasing amounts of fli1 mRNA (lanes 2-5) and then allowed to develop until stage 17. After the embryos were homogenized, the proteins were Freon-extracted, separated by SDS-PAGE, and transferred to a nitrocellulose membrane. The western blot was probed with a 1/500 dilution of Fli1 anti-serum. After removal of the primary antibody, the blot was incubated with a 1/5000 dilution of donkey anti-sheep secondary antibody conjugated to horseradish peroxidase. The blot was developed using ECL Prime Western Blotting Detection Reagent (GE Healthcare). The band corresponding to Fli1 protein increases in intensity with increasing fli1 mRNA injection amounts. The last lane (lane 6) is the protein from a fli1 in vitro translation (Promega), showing that the Fli1 protein produced by in vitro translation is the same size as Fli1 protein in Xenopus laevis embryos.

iv. Centrifuge the sample at $21,000 \mathrm{~g}$ for $3 \mathrm{~min}$ at $4^{\circ} \mathrm{C}$.

v. Collect the upper (protein) phase.

35. Separate proteins by SDS-PAGE, loading 0.5-1 embryo equivalent of crude protein extract per well in the SDS-PAGE sample buffer.

36. Follow standard western blotting protocols to test the specificity of the antibody of interest.

Noninjected embryo samples should produce a band at the size expected for your protein of interest. If the antibody is detecting the target protein, CRISPR-injected embryos will show a weaker band, and the RNAinjected embryos will show a stronger band. For an example of the latter, see Figure 1.

Once an antibody has been raised against a target protein (see Protocol: Raising Antibodies for Use in Xenopus [Piccinni and Guille 2020]), various strategies can be used to verify that the new antibody recognizes its target. Sometimes using immunoprecipitation, tryptic digest, and mass spectroscopy of the target protein is the only convincing approach (Persson et al. 2017). In a well-established model like Xenopus, however, inducing loss or gain of function of the target protein in embryos followed by western blotting is a straightforward, powerful alternative strategy. Target protein can be knocked down using either CRISPR-Cas9 technology (Nakayama et al. 2014), as described here, or an antisense morpholino oligonucleotide (AMO; Heasman et al. 2000). Both have good penetrance when the target is not maternal. CRISPR-Cas9 is cheaper than AMO, and it is straightforward to confirm that insertion or deletion of sequence at the target site has occurred by using sequencing or T7 endonuclease. However, for AMOs targeting translation, there is no such simple positive control. For these reasons, knockdown by CRISPR-Cas9 is described here. For maternal proteins, microinjection of a synthetic mRNA encoding the target to increase its expression is preferable (Guille 1999; see Fig. 1). 
Martin et al.

Embryo Extraction Buffer

$10 \mathrm{~mm}$ HEPES (pH 8.5)

$2 \mathrm{mM} \mathrm{MgCl}_{2}$

$1 \mathrm{~mm}$ EDTA

$10 \mathrm{~mm} \beta$-glycerophosphate

$1 \mathrm{~mm}$ dithiothreitol (DTT)

Store for up to 1 wk at $4^{\circ} \mathrm{C}$.

Modified Barth's Saline (MBS) (1×, pH 7.8)

\begin{tabular}{lcc} 
Reagent & Quantity (for 1 L) & Final concentration $(1 \times)$ \\
\hline $\mathrm{NaCl}$ & $5.143 \mathrm{~g}$ & $88 \mathrm{~mm}$ \\
$\mathrm{KCl}$ & $0.075 \mathrm{~g}$ & $1 \mathrm{~mm}$ \\
$\mathrm{MgSO}_{4}$ & $0.120 \mathrm{~g}$ & $1 \mathrm{~mm}$ \\
$\mathrm{HEPES}$ & $1.192 \mathrm{~g}$ & $5 \mathrm{~mm}$ \\
$\mathrm{NaHCO}_{3}$ & $0.210 \mathrm{~g}$ & $2.5 \mathrm{~mm}$ \\
$\mathrm{CaCl}_{2}$, dihydrate & $0.103 \mathrm{~g}$ & $0.7 \mathrm{~mm}$
\end{tabular}

to $1 \mathrm{~L}$

Adjust the $\mathrm{pH}$ to 7.8 with $10 \mathrm{~m} \mathrm{NaOH}$ and sterilize by autoclaving. Store at room temperature indefinitely.

Guille M. 1999. Microinjection into Xenopus oocytes and embryos. Methods Mol Biol 127: 111-123. doi:10.1385/1-59259-678-9:111

Guille M, Robinson C. 1999. Immunohistochemistry of Xenopus embryos. Methods Mol Biol 127: 89-97. doi:10.1385/1-59259-678-9:89

Heasman J, Kofron M, Wylie C. 2000. $\beta$-catenin signaling activity dissected in the early Xenopus embryo: a novel antisense approach. Dev Biol 222: 124-134. doi:10.1006/dbio.2000.9720

Nakayama T, Blitz I, Fish M, Odeleye A, Manohar S, Cho K, Grainger R. 2014. Cas9-based genome editing in Xenopus tropicalis. Methods Enzymol 546: 355-375. doi:10.1016/B978-0-12-801185-0.00017-9
Persson H, Preger C, Marcon E, Lengqvist J, Gräslund S. 2017. Antibody validation by immunoprecipitation followed by mass spectrometry analysis. Methods Mol Biol 1575: 175-187. doi:10.1007/978-1-49396857-2_10

Piccinni MZ, Guille MJ. 2020. Raising antibodies for use in Xenopus. Cold Spring Harb Protoc doi:10.1101/pdb.prot105585.

Rupp RA, Snider L, Weintraub H. 1994. Xenopus embryos regulate the nuclear localization of XMyoD. Genes Dev 8: 1311-1323. doi:10.1101/ gad.8.11.1311 


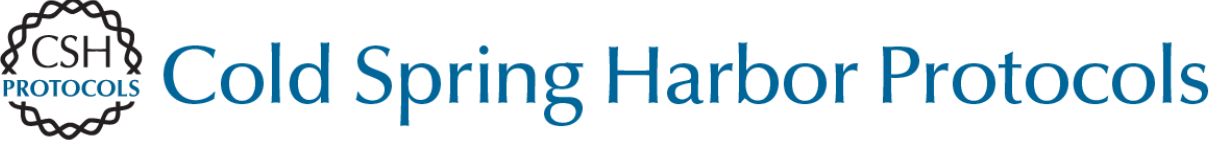

\section{Confirming Antibody Specificity in Xenopus}

Sian A. Martin, Suzannah J. Page, Maya Z. Piccinni and Matthew J. Guille

Cold Spring Harb Protoc; doi: 10.1101/pdb.prot105601 originally published online October 9, 2020

\begin{tabular}{|c|c|}
\hline $\begin{array}{r}\text { Email Alerting } \\
\text { Service }\end{array}$ & Receive free email alerts when new articles cite this article - click here. \\
\hline $\begin{array}{l}\text { Subject } \\
\text { Categories }\end{array}$ & $\begin{array}{l}\text { Browse articles on similar topics from Cold Spring Harbor Protocols. } \\
\text { Antibodies ( } 119 \text { articles) } \\
\text { Antibodies, general (289 articles) } \\
\text { Generating Antibodies (71 articles) } \\
\text { Generating Antibodies, general (60 articles) } \\
\text { Immunodetection ( } 34 \text { articles) } \\
\text { Sampling Serum (7 articles) } \\
\text { Xenopus (210 articles) }\end{array}$ \\
\hline
\end{tabular}

